\title{
オフィスの緑化された共用空間における就業者の利用実態および利用 頻度や利用意識に影響する要因
}

\section{小島倫直 $\left.{ }^{* 1}\right)$ ：花里真道 2)－石川敦雄 ${ }^{3)}$ ：岩崎 寛 4)}

1）株式会社竹中工務店技術研究所 Research \& Development Institute, Takenaka Corporation

2）千葉大学予防医学センター Center for Preventive Medical Sciences, Chiba University

3）京都府立大学大学院生命環境科学研究科 Graduate School of Life and Environmental Sciences, Kyoto Prefectural University

4) 千葉大学大学院園芸学研究院 Graduate School of Horticulture, Chiba University

摘要 : オフィスにおけるストレス緩和や知的生産性向上などの効果を目的とした室内緑化が注目されている。しかし，オフィスに設 けられた緑化空間が実際に就業者に利用されているかの検証は十分には行われていない。そこでオフィスの緑化された共用空間を対 象に，就業者の利用実態に関するアンケートを実施した。そして得られた回答結果をもとにグラフィカルモデリングを用いて利用要 因を抽出した。その結果, 利用頻度には, 就業者の利用意識や就労形態, 緑化された共用空間の建物内配置という多様な要因が影響を 与えていることが示唆された。共用空間の緑化計画時に, 利用促進を図るために配慮が必要な要因を把握することができた。 キーワード : 室内緑化, バイオフィリックデザイン, オフィス環境, グラフィカルモデリング

KOJIMA, Michinao, HANAZATO, Masamichi, ISHIKAWA, Atsuo, and IWASAKI, Yutaka: Actual usage and the key factors influencing attitudes toward the use of common space incorporating biophilic design in an office

Abstract: Indoor green is now being used in common spaces in offices with the expectation that it will improve intellectual productivity. However, there has not been sufficient verification of whether the installed common space incorporating biophilic design is used by the workers. Therefore, we conducted a questionnaire survey on the actual status of workers' use of office greening common spaces. Graphical modeling was then applied to the response results to extract usage factors. The results suggest that the frequency of use of green common spaces in offices is influenced by a variety of factors, such as workers' awareness of their use, working patterns, and the layout of green common spaces in buildings. We were able to identify factors that need to be taken into consideration when planning green common spaces to promote their use.

Key words: interior green, biophilic design, office environment, graphical modelling

\section{1. 背景}

就業者が働くオフィスにおいて建物・施設視点から健康を サポートする環境評価手法の構築が進んでいる。その代表的 な評価体系として CASBEE-ウェルネスオフィス 7)や Well

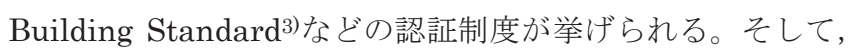
いずれの認証制度でも評価項目の一つとして採用されている のが, 室内への緑化など自然要素の導入である。これまで緑 化空間の利用により得られる効用について, 多くのエビデン スが得られ整理されてきた ${ }^{1)}$ 。一方，才フィスにおける緑化 計画の際に問題となるのが導入コストである。特に室内緑化 は, 病害虫防除や清掃等維持管理でも一定のコストがかかる。 このため全面的に緑化を導入することは難しく, 生産性向上 など効果と導入コストを比較したプロダクティビティ評価の 観点 ${ }^{11)}$ から導入範囲検討が必要である。

ここで，限られた緑化空間で，より多くの効果を得るの
に有効と考えられるのが，不特定多数の就業者が執務で利用 する打合せ室や休䄭室など共用空間の緑化である。共用空間 に緑化を設けて，オフィスビル全体の就業者がその空間に作 業や打合せなどの執務に訪れるようになれば，限られた面積 の共用空間でも多くの就業者が緑化の効能を享受できる。そ のためには, オフィスの緑化された共用空間に対して, 就業 者の利用を促進する計画手法が必要になる。

既往の研究で，オフィスにおける執務場所の選択には，作 業内容や個人の選好性が影響する8)ことが示されている。ま た, 屋外の緑化された公共空間である都市公園では, 都市公 園の交流場所としての位置づけが利用の有無に影響する6)こ とが分かっている。こうした空間に対する個人の選好性や利 用要因を解明することで, 空間計画時に利用を促進するため の配慮が可能になると考えられる。しかしオフィスに設けら れた緑化された共用空間における就業者の利用実態を調査し た事例はほとんどなく，計画に必要な知見が不足している。

\footnotetext{
* 連絡先著者 (Corresponding author) : ̄270-1352 千葉県印西市大塚 1-5-1 E-mail : kojima.michinao@takenaka.co.jp
} 


\section{2. 目的}

就業者はオフィスに設けられた緑化空間の利用により，心 理的効果を享受できる13）ことなどが明らかにされてきた。 一方で，これらの知見は緑化空間を利用することが前提で, 緑化空間が就業者に実際に利用されているかは検討されてい ない。今後のオフィスでは, 緑化空間を就業者にいかに提供 して利用される場にするか, という緑化空間の利用促進に関 する知見が必要になる。そこで本報ではオフィスの緑化され た共用空間（以下，緑化共用空間と表記する。）を対象に, 就業者の利用実態を明らかにし, 利用頻度や利用意識の形成 に関わる要因を明らかにすることを目的とする。

\section{3. 方法}

3.1 緑化共用空間の利用実態アンケート調査

緑化共用空間が設けられたオフィスの就業者を対象に，以 下に示す利用実態を調査するアンケートを実施した。

\section{1 .1 調查対象}

調査対象は，総合建設業を業態とする企業グループが占有 している地上 7 階建てオフィスビル(東京都江東区 延床面 積 $29,781 \mathrm{~m}^{2}$ 竣工 2004 年)である。2018 年までは，このビ ルの屋内には観葉植物のプランターが点在する程度の植物し かなかったが， 2018 年 10 月にビル 6 階に $230 \mathrm{~m}^{2}$ の緑化共 用空間が開設された(写真- 1$)$ 。空間には植物に加え, 水盤, 木 製什器などの自然要素が取り入れられている。また，カウン ター席やソファ席など様々な座席が設けられ, PC を用いた 一人での執務や打合せ，休憩など，多様な執務が可能な共用 空間として就業者に常時開放されている。

\subsection{2 調查方法}

調査対象のオフィスビルで働く就業者 1,680 人に対して, 2019 年 7 月 16 日〜26 日にかけてオンラインアンケートを 実施した。アンケートサイトは, 調査対象企業のイントラネ ット内にオンラインアンケートシステム LimeSurvey ver.1.9.2 を用いて構築した。事前に構築したアンケートサイ トURL を対象企業社内メーリングリストで一斉配信し，ア ンケートを開始した。

\subsection{3 アンケート設問}

緑化共用空間の利用には, 個人の自然要素に対する啫好や 従事する仕事の状態など, 多様な要因が関わると考えられた。 しかし, 先行の研究例がほとんどない。そこでアンケート設 問は共著者間で討議を行い，利用に影響すると考えた(1)自然 観, (2)就労状態, (3)勤務環境評価, (4)対象空間評価, (5)配置 計画評価, 6利用, 以上 6 つの大項目を設定した。その上で, それぞれに関わる問いを設けてアンケート設問とした。

また, 就業者の執務における緑化共用空間の利用には, PC による事務作業や資料作成，一人でのアイデア検討など，一 人での執務（以下，一人作業と表記する。）や，多人数での 打合せ，執務の合間の休憩などの行動が考えられた。本報で

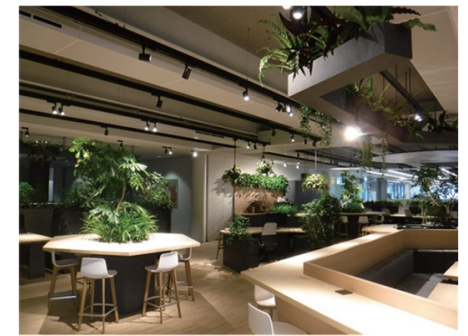

写真-1 調査対象の緑化共用空間

Photo 1 Green space to be surveyed

は，こうした行動のうち，特に一人作業に着目して緑化共用 空間の利用実態を解析する。一人作業は，多くの職種で必要 な執務である。また，打合せのように，一緒に作業する他者 を必要とする執務ではない。このため一人作業をする時の緑 化共用空間の利用実態を把握することで, 個人の意思に基づ いて緑化共用空間の利用に至った経緯や, 個人の就労状態や 勤務環境が利用状況に与える影響を明らかにすることができ ると考えた。

アンケート設問を表- 1 に示す。大項目 [自然観]のうち，[自 然観回復感]および[自然観一体感]は, 自然に対する感情反応 尺度 9)に基づく問いを各 3 問ずつ設定し，3 問の総合得点を 評価值として解析に用いる。本尺度は自然に対して持つ感情 について，その反応の大きさを評価するために提案された尺 度で，自然観の把握に有効であると考え採用した。同様に， 大項目 [就労状態]の[仕事コントロール]および[仕事量的負担] は, 2015 年から労働安全衛生法のもと義務化された労働者の ストレスチェック 4)で, 国から質問票として推奨されている 職業性ストレス指標 ${ }^{10)}$ に基づき問いを各 3 問ずつ設定し，3 問の総合得点を評価值とした。

大項目 [就労状態]の[ABW 該当]では，仕事内容に応じて執 務場所を自由に選択することが可能な Activity Based Working ${ }^{12)}$ （以下，ABW と表記する。）という勤務形態の 適用有無を尋ねた。 $\mathrm{ABW}$ は, 就業者に高い働き方裁量が与 えられており, 就業者が共用空間の利用を検討する際に重要 な要因になると考えられる。

大項目 [利用]の[利用頻度]は, 緑化共用空間を一人作業で利 用する頻度について回答を求めた。頻度は, ”ほぼ毎日” “週に 3-4 回程度”“週に 1-2 回程度”“2 週に 1 回程度”“月に 1 回以下”の 5 段階評価とし，2 週に 1 回程度以上緑化共用空 間を利用する就業者を，本報では利用者と定義する。また， 相関係数などを算出する際は, 各尺度を月の利用回数に換算 して定量尺度として解析に適用する。

3.2 解析方法

本報の目的は，緑化共用空間の利用に関わる要因を把握 し，利用促進に寄与する知見を得ることである。これは[利 用頻度]と高い相関係数を示す要素を明らかにすることで把 握できると考えられる。しかし相関係数は，2要素が直接関 係無くても，他の同一要素と関係がある時，表向き高い相関 
係数が示される擬似相関が生じることが知られている。擬似 相関は，本来は因果関係がない要素間に関係があると誤った 結論を導くことがある。

そこで直接的な因果関係にある要素を把握して，緑化共用 空間の利用要因を抽出するため, 本報ではアンケート結果に グラフィカルモデリング（以下，GMと表記する。）を適用 する。GMは2要素間の直接的な相関関係を示す偏相関係数 行列をもとに，各要素間が条件付き独立，すなわち直接的な 関係がないとみなせるかどうかを判定する手法である。GM は以下の手順5)で実施する。

(1)要素間の相関係数を網羅した相関行列を算出する。得られ た相関行列を標本相関行列と定義する。

(2)相関行列から，要素間の偏相関行列を算出する。偏相関行 列のうち, 最も低い偏相関係数を示す要因間の関係を独立 であると仮定し，偏相関係数を 0 とする。

(3)(2)で新たに得られた偏相関行列を仮定した時の, 要素間の 相関行列を推定する。この時, 独立と仮定した要素間以外 の相関係数は, 推定前の相関係数から不変とする。

(4)(3)で得られた推定相関行列と, もともとの標本相関行列と の差を求め, 逸脱度を算出する。逸脱度を指標として, カ イ二乗分布を仮定してp值を算出する。

(5) p值が一定值以上の時, (2)で仮定した要素間が独立の関係 にあることが採択されたと考える。本検討では文献12)を参 考にp值0.5以上を採択基準とした。

(6)仮定したモデルが採択された場合, (3)で推定した相関行列 を用いて, (2)以降の手順を繰り返す。繰り返しは, p 值が

(5)で設定した閾值以下になるまで行う。

\section{4. 結果と考察}

アンケート期間内に 876 人分の回答を回収した（回収率 $52.1 \%)$ 。回収サンプルのうち, 久測データを含むサンプルを 除き 811 人分を分析対象とした。回答者の性別属性は, 男性

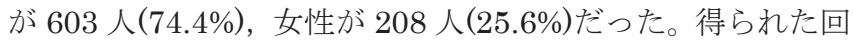
答結果を以下に示す。

\section{1 就業者の緑化共用空間に対する評価}

\subsection{1 就業者の自然観}

緑化空間の評価には，就業者の自然観が影響すると予想さ れる。そこで大項目 [自然観 $の$ 回答結果を確認する。

[自然観回復感 および[自然観一体感]は, 各 3 つの設問の 5 段階評価尺度の合計点を評点としている。合計点は 3 15 点 で, 中立が 9 点, それ以上 $(10 \sim 15$ 点)が肯定的評価で, それ 以下 $(3 \sim 8$ 点)が否定的評価とみなせる。[自然観回復感]では $85.1 \%$, [自然観一体感]では $64.0 \%$ の就業者が肯定的評価であ つた。就業者の過半数が, 自然に肯定的な印象を持つことが わかった。また，オフィスに植物があると良いと思うかを尋 齐た[オフィスに緑]では, 就業者のうち”そう思う”と回答し たのは $48.2 \%$, ”ややそう思う”と回答したのは $35.6 \%$, 計 $83.8 \%$ の就業者が肯定的に評価した。
表-1 アンケート設問一覧

Table 1 List of questions

\begin{tabular}{|c|c|c|c|c|c|}
\hline & 項目 & 設問 & 尺度数 & & 回答 \\
\hline \multirow{8}{*}{$\begin{array}{l}\text { 自 } \\
\text { 然 } \\
\text { 観 }\end{array}$} & $\begin{array}{l}\text { 自然観 } \\
\text { 回復感1 }\end{array}$ & きれいな草花を見ると楽しくなる。 & 5 & $\begin{array}{l}\text { 当て } \\
\text { はまる }\end{array}$ & $\begin{array}{c}\text { 当て } \\
\text { はまらない }\end{array}$ \\
\hline & $\begin{array}{l}\text { 自然観 } \\
\text { 回復感2 }\end{array}$ & 木々の緑に癒しを感じる。 & 5 & $\begin{array}{l}\text { 当て } \\
\text { はまる }\end{array}$ & $\begin{array}{c}\text { 当て } \\
\text { はまらない }\end{array}$ \\
\hline & $\begin{array}{l}\text { 自然観 } \\
\text { 回復感3 }\end{array}$ & $\begin{array}{l}\text { 緑豊かな自然を眺めていると疲れが吹き } \\
\text { 飛ぶ。 }\end{array}$ & 5 & $\begin{array}{l}\text { 当て } \\
\text { はまる }\end{array}$ & $\begin{array}{c}\text { - 当て } \\
\text { はまらない }\end{array}$ \\
\hline & $\begin{array}{l}\text { 自然観 } \\
\text { 一体感1 }\end{array}$ & 自然環境に対して強い愛着を感じる。 & 5 & $\begin{array}{l}\text { 当て } \\
\text { はまる }\end{array}$ & 一 $\begin{array}{c}\text { 当て } \\
\text { はまらな }\end{array}$ \\
\hline & $\begin{array}{l}\text { 自然観 } \\
\text { 一体感2 }\end{array}$ & $\begin{array}{l}\text { 自然の中に自分の居場所のようなものを } \\
\text { 感じる。 }\end{array}$ & 5 & $\begin{array}{l}\text { 当て } \\
\text { はまる }\end{array}$ & 一 $\begin{array}{c}\text { 当て } \\
\text { はまらない }\end{array}$ \\
\hline & $\begin{array}{l}\text { 自然観 } \\
\text { 一体感3 }\end{array}$ & 自然との一体感を強く感じる。 & 5 & $\begin{array}{l}\text { 当て } \\
\text { はまる }\end{array}$ & $\begin{array}{c}\text { 当て } \\
\text { はまらない }\end{array}$ \\
\hline & 日常に緑 & 日常生活に緑(植物)があるとよいと思う。 & 5 & そう思う & - 思わない \\
\hline & オフィスに緑 & オフィスに緑(植物)があるとよいと思う。 & 5 & そう思う & - 思わない \\
\hline \multirow{8}{*}{$\begin{array}{l}\text { 就 } \\
\text { 労 } \\
\text { 状 } \\
\text { 態 }\end{array}$} & $\begin{array}{l}\text { 一人作業 } \\
\text { 頻度 }\end{array}$ & 社内でー人作業を行う頻度 & 5 & ほぼ毎日 & $\begin{array}{c}\text { 月に } \\
-1 \text { 1回以下 }\end{array}$ \\
\hline & $\begin{array}{c}\text { 仕事 } \\
\text { コントロール1 }\end{array}$ & 自分のペースで仕事ができる。 & 4 & そうだ & - ちがう \\
\hline & $\begin{array}{c}\text { 仕事 } \\
\text { コントロール2 }\end{array}$ & $\begin{array}{l}\text { 自分で仕事の順番·やり方を決めることが } \\
\text { できる。 }\end{array}$ & 4 & そうだ & - ちがう \\
\hline & $\begin{array}{c}\text { 仕事 } \\
\text { コントロール3 }\end{array}$ & $\begin{array}{l}\text { 職場の仕事の方針に自分の意見を反映で } \\
\text { きる。 }\end{array}$ & 4 & そうだ & - ちがう \\
\hline & $\begin{array}{c}\text { 仕事 } \\
\text { 量的負担1 }\end{array}$ & $\begin{array}{l}\text { 非常にたくさんの仕事をしなければならな } \\
\text { い。 }\end{array}$ & 4 & ちがう & - そうだ \\
\hline & $\begin{array}{c}\text { 仕事 } \\
\text { 量的負担2 }\end{array}$ & 時間内に仕事が処理しきれない。 & 4 & ちがラ & - そうだ \\
\hline & $\begin{array}{c}\text { 仕事 } \\
\text { 量的負担3 }\end{array}$ & 一生懸命働かなければならない。 & 4 & ちがラ & - そうだ \\
\hline & $\begin{array}{l}\text { ABW } \\
\text { 該当 }\end{array}$ & ABW (Activity Based Working) 該当者 & 2 & 該当する & - 該当しない \\
\hline \multirow{4}{*}{$\begin{array}{l}\text { 勤 } \\
\text { 務 } \\
\text { 環 } \\
\text { 境 } \\
\text { 評 } \\
\text { 価 }\end{array}$} & $\begin{array}{l}\text { 現状座席 } \\
\text { 満足 }\end{array}$ & $\begin{array}{l}\text { 所属部署のスペースは、一人作業をする } \\
\text { のに適している。 }\end{array}$ & 5 & そう思う & - 思わない \\
\hline & $\begin{array}{l}\text { 場所選択 } \\
\text { 意向 }\end{array}$ & $\begin{array}{l}\text { 一人作業をする時は、出来れば好きな場 } \\
\text { 所で行いたい。 }\end{array}$ & 5 & そう思う & - 思わない \\
\hline & 離席可否 & $\begin{array}{l}\text { 所属部署では、一人作業をするために離 } \\
\text { 席することには否定的な雰囲気がある。 }\end{array}$ & 5 & 思わない & - そう思う \\
\hline & $\begin{array}{c}\text { 作業 } \\
\text { 代替場所 }\end{array}$ & $\begin{array}{l}\text { 一人作業を行うなら、評価対象空間よりも } \\
\text { 良い場所が社内にある。 }\end{array}$ & 5 & 思わない & - そう思う \\
\hline \multirow{4}{*}{$\begin{array}{l}\text { 対 } \\
\text { 象 } \\
\text { 空 } \\
\text { 間 } \\
\text { 評 } \\
\text { 価 }\end{array}$} & $\begin{array}{l}\text { 評価空間 } \\
\text { 認知 }\end{array}$ & 評価対象空間のことを知っている。 & 5 & $\begin{array}{l}\text { 知って } \\
\text { いる }\end{array}$ & - 知らない \\
\hline & $\begin{array}{l}\text { 評価空間 } \\
\text { 美観 }\end{array}$ & $\begin{array}{l}\text { 評価対象空間の緑(植物)は美観的に良 } \\
\text { いと思う。 }\end{array}$ & 5 & そう思う & - 思わない \\
\hline & $\begin{array}{l}\text { 評価空間 } \\
\text { 好ましさ }\end{array}$ & $\begin{array}{l}\text { 評価対象空間は、好ましいオフィス環境と } \\
\text { 思う。 }\end{array}$ & 5 & そう思う & - 思わない \\
\hline & $\begin{array}{l}\text { 評価空間 } \\
\text { 作業適性 }\end{array}$ & $\begin{array}{l}\text { 評価対象空間には、一人作業に適した席 } \\
\text { がある。 }\end{array}$ & 5 & そう思う & - 思わない \\
\hline \multirow{3}{*}{$\begin{array}{l}\text { 配 } \\
\text { 置 } \\
\text { 計 } \\
\text { 画 } \\
\text { 評 } \\
\text { 価 }\end{array}$} & $\begin{array}{l}\text { 評価空間 } \\
\text { 距離 }\end{array}$ & 自席がある区画から距離算出 & 50 & 館内を 50 & 0区画に分割 \\
\hline & $\begin{array}{l}\text { 評価空間 } \\
\text { 距離感 }\end{array}$ & $\begin{array}{l}\text { 評価対象空間は、一人作業をしに行くには } \\
\text { 遠いと感じる。 }\end{array}$ & 5 & 思わない & - そう思う \\
\hline & $\begin{array}{l}\text { 評価空間 } \\
\text { 混雑感 }\end{array}$ & $\begin{array}{l}\text { 評価対象空間では、一人作業をしようとし } \\
\text { ても席が空いていなかったり、他の利用者 } \\
\text { が気にななったしてやりにこいことが多い。 }\end{array}$ & 5 & 思わない & - そう思う \\
\hline \multirow{2}{*}{$\begin{array}{l}\text { 利 } \\
\text { 用 }\end{array}$} & 利用意識 & $\begin{array}{l}\text { 一人作業を行う際に、機会があれば評価 } \\
\text { 対象空間 を積極的に利用したい。 }\end{array}$ & 5 & そう思う & - 思わない \\
\hline & 利用頻度 & $\begin{array}{l}\text { 一人作業を行う際に評価対象空間を利用 } \\
\text { する頻度 }\end{array}$ & 5 & ほぼ毎日 & $-\underset{\text { 月に }}{\text { 月に }}$ \\
\hline
\end{tabular}

\subsection{2 就業者の緑化共用空間に対する評価}

前項では, 自然やオフィス緑化に対して過半数の就業者が 肯定的評価をしていることが確認できた。次に実際にオフィ スに設置された緑化共用空間(写真-1)の評価を把握する。大 項目[対象空間評価]の結果を図-1に示した。評価空間美観 [評価空間好ましさ]では，それぞれ $67.0 \%, 67.7 \%$ の就業者が 肯定的に評価していた。一方，一人作業に適しているかを尋 ねた[評価空間作業適性]では, 肯定的評価は $46.8 \%$ となり, 過半数に満たなかった。空間の作業適性評価には, 美観や好 ましさという印象以外の要素も影響することが示唆された。 
4.2 就業者の緑化共用空間における利用実態

\subsection{1 就業者の利用意識と利用頻度}

緑化共用空間の利用実態を明らかにするため, 大項目 [利 用]では, 機会があれば一人作業に積極的に利用したいかを尋 ねる[利用意識], および一人作業での利用頻度を尋ねる[利用 頻度]の設問 2 点を設けた。回答結果を図-2 に示した。

[利用意識]では, ”そう思う”および”ややそう思う”という 肯定的評価をした就業者は $38.3 \%$ あった。

また，[利用頻度]では，“ほぼ毎日”利用している人は 5 名 (0.6\%), ”週に $2-3$ 回程度”利用している人は 33 名 $(4.1 \%)$, ”週に 1 回程度”利用している人は 73 名(9.0\%), 2 週に 1 回 程度”利用している人は 97 名(12.0\%), ”月に 1 回以下”利用 の人は 603 名 $(74.4 \%)$ であった。調査対象の緑化共用空間が 占める床面積 $\left(230 \mathrm{~m}^{2}\right)$ は, 建物延べ床面積 $\left(29,781 \mathrm{~m}^{2}\right)$ の $0.77 \%$ である゙， $25.6 \%$ の就業者が一人作業で 2 週に 1 回程 度は利用していた。限られた面積の緑化空間でも，多くの就 業者が利用している事がわかる。これがオフィスの共用空間 を緑化する利点と言える。一方, [利用意識]に肯定的な評価を していた就業者の割合(38.3\%)よりも, 実際に利用している就 業者の割合 $(25.6 \%)$ は少ないことも分かった。そこで[利用意 識] と[利用頻度]の比較のためクロス集計を行った(表-2)。 利用意識が高まるにつれ，2 週に 1 回程度以上の頻度で緑化 共用空間を利用する就業者の割合が高くなる一方，[利用意 識]が最も高い就業者層でも，その割合は $65.0 \%$ にどまっ た。緑化共用空間を利用する気持ちがありながら，実際には 利用できていない就業者が存在することが示された。

\section{2 .2 自然観と利用実態}

自然観に関わる設問[オフィスに緑]では, 8 割を超える就業 者がオフィスに緑があることについて肯定的評価したのに比 べると, 設置された緑化共用空間に対する利用意識の高い就 業者や実際の利用者が少ないことも明らかになった。オフィ スに緑があることに対する肯定的な評価だけでは，緑化共用 空間の利用に繋がらないことが示された。

\subsection{3 グラフィカルモデリング(GM)による要因把握}

利用に影響を与える要因をより詳細に把握するため, アン ケート回答結果に GM を適用した。GM 適用前の要素閒相関 係数と, GM 適用後の要素間の偏相関係数を比較し図-3 に示 した。要素閒が条件付き独立関係にあると判定された時, GM 適用後の要素間の偏相関係数は 0 となる。図-3より, 要素間 の相関係数が比較的高い 0.4 以上でも，条件付き独立の関係 にあると判定された要素があることがわかる。GM 適用の結 果，210 対の要素間関係のうち，135 対が条件付き独立の関 係にあると判定された。残りの 75 対を GM で得られた偏相 関係数に基づき，図-4 に図示した。[利用意識]と比較的高い 偏相関係数 $(0.15$ 以上)を示寸要素は，[利用頻度] [場所選択意 向] [作業代替場所] [評価空間作業適性]の 4 要素であった。一 方, [利用頻度] と比較的高い偏相関係数を示す要素は, [利用

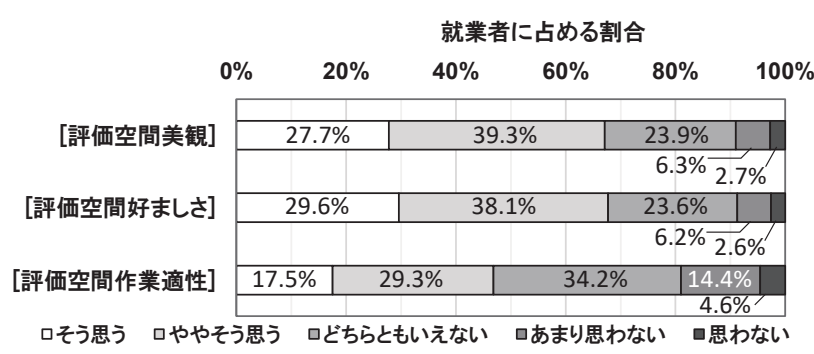

図-1 調查対象の緑化共用空間に対する評価

Fig. 1 Evaluation of green common space

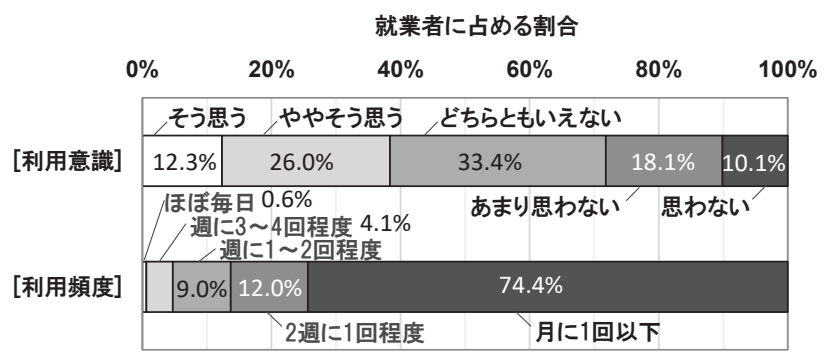

図-2 緑化共用空間の利用実態

Fig. 2 Actual usage of green common space

表-2 利用頻度と利用意識のクロス集計

Table 2 Cross tabulation of actual usage

\begin{tabular}{|c|c|c|c|c|c|c|c|}
\hline & & \multicolumn{5}{|c|}{ 利用意識ごとの利用頻度該当者数(人) } & \multirow{2}{*}{$\begin{array}{c}\text { 利用意識ごとの } \\
\text { 2週にに和回以上利用する } \\
\text { 就業者の割合 }\end{array}$} \\
\hline & & $\begin{array}{l}\text { ほぼ } \\
\text { 毎日 }\end{array}$ & $\begin{array}{c}\text { 週に } \\
\text { 2-3回程度 }\end{array}$ & $\begin{array}{c}\text { 週に } \\
\text { 1回程度 }\end{array}$ & $\begin{array}{c}\text { 2週に } \\
\text { 1回程度 }\end{array}$ & $\begin{array}{c}\text { 月1回 } \\
\text { 以下 }\end{array}$ & \\
\hline & 1 & 0 & 0 & 0 & 1 & 81 & $1.2 \%$ \\
\hline & 2 & 0 & 0 & 2 & 6 & 139 & $5.4 \%$ \\
\hline 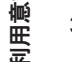 & 3 & 0 & 2 & 12 & 26 & 231 & $14.8 \%$ \\
\hline$\frac{1}{d}$ & & 2 & 12 & 30 & 50 & 117 & $44.5 \%$ \\
\hline & 5 & 3 & 19 & 29 & 14 & 35 & $65.0 \%$ \\
\hline
\end{tabular}

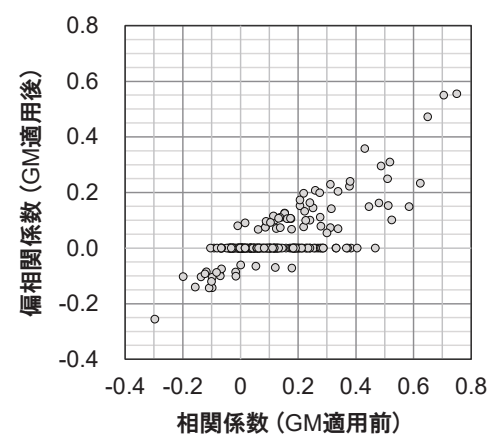

図-3 要素間相関係数と GM 適用後偏相関係数の比較

Fig.3 Correlation coefficient and partial correlation coefficient

意識] [ABW 該当] [評価空間距離感]の 3 要素で, 直接的な相 関関係にある要素が[利用意識]と異なった。 
4.3 緑化共用空間の利用に影響する要因

\subsection{1 利用頻度に強く影響する要因}

GM で示された要素間の関係のうち，偏相関係数の絶対值 が 0.15 以上を示した要素間において,一般に弱い相関がある 2) と言われる相関係数 0.2 以上を示すことが確認できた(図3)。そこで特に偏相関係数の絶対值が 0.15 以上を示した 21 対の要素間の関係に着目し，図-5に示した。これにより就業 者が緑化共用空間の利用にいたるまでの主要因およびプロセ スを把握し，利用促進に向けた方策の検討が可能になると考 えた。

表-2 では, 緑化共用空間を利用する意識がありながら利用 できていない就業者の存在が示唆されていた。図-5では, [利 用頻度]には，[利用意識]以外に [評価空間距離感] $[\mathrm{ABW}$ 該 当]も影響することが示された。こうした利用意識以外の要因 に影響を受け，緑化共用空間を利用できなかった可能性があ る。そこで, 各要因が[利用頻度]に与える影響の大きさを把握 する。調査対象とした緑化共用空間を機会があれば積極的に 利用したいか尋ねた[利用意識]では”そう思う” “ややそう思 う”という肯定的評価群とそれ以外の群, [評価空間距離感] では緑化共用空間までの距離感について“遠いと思わない” “あまり遠いと思わない”という肯定的評価群とそれ以外の 群, [ABW 該当]では”ABW 該当”と”ABW 非該当”の群, そ れぞれ 2 群に就業者を分類し, 各群に属する就業者の緑化共 用空間を利用する頻度を求めた(図-6)。[利用意識]では，肯 定的評価をした就業者のうち, 緑化共用空間を 2 週に 1 回以 上利用した就業者は $51.1 \%$ あった。一方, 非肯定的評価群 では, その割合は $9.8 \% に$ 留まった。同様に[評価空間距離感] では, 肯定的評価群のうち 2 週に 1 回以上利用した就業者は $46.2 \%$, 非肯定評価群では $14.2 \%$ あった。また[ABW 該当] では, $\mathrm{ABW}$ 該当就業者は $49.7 \%, \mathrm{ABW}$ 非該当就業者は 18.4 $\%$ が緑化共用空間を 2 週に 1 回以上利用した。

以上より，図-5 で示された[利用頻度]と関係がある 3 つの 主要因が, 利用に影響することが確認できた。なお[利用意識] と[評価空間距離感 について共に肯定的評価をし, かつ ABW に該当する就業者は 60 名存在した。そのうち緑化共用空

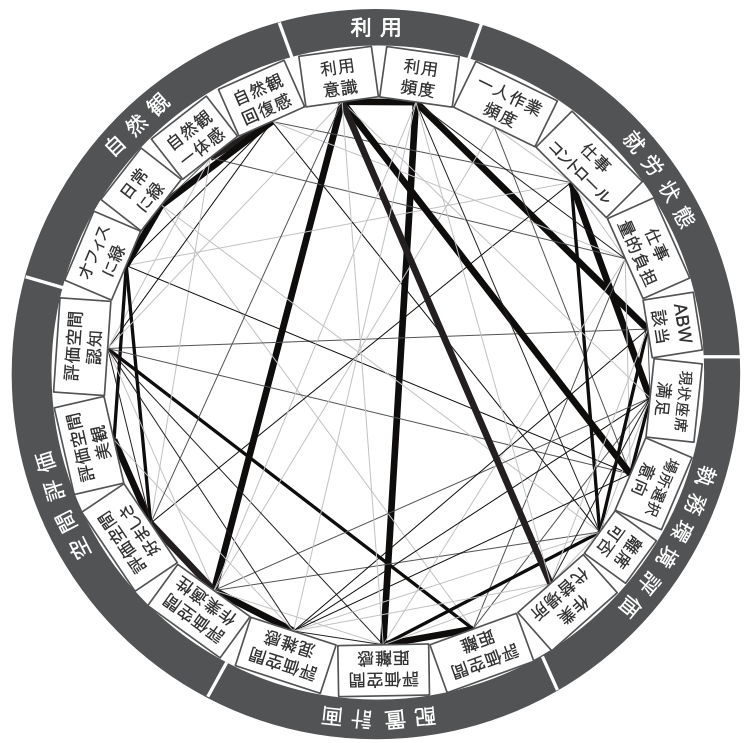

GM適用後偏相関係数(絶対値)

0.10 未満 -0.10 以上 0.15 未満 -0.10 以上 0.15 未満 -0.20 以上

図-4 GM 適用により示された要素間関係図

Fig. 4 Element relation diagram based on graphical modelling

間を 2 週に 1 度以上利用している就業者は $85.0 \%$ にった。

4.3.2 利用意識の形成に強く影響する要因

[利用意識]は[利用頻度]の他に[評価空間作業適性] [作業代 替場所] [場所選択意向]と直接の影響関係にあると考えられ た(図-5)。利用意識の形成には, 緑化共用空間が作業に適して いるかに加え, 就業者が作業する場所を選んで執務をしたい と考えているか, 緑化共用空間よりも良い一人作業できる場 所がオフィス内にあるかという, 就労スタイルや執務環境が 影響することが示唆された。

また, 図-5 では, [評価空間作業適性] は, [評価空間好まし さ]と[混雑感]から強く影響を受けている。さらに[評価空間好 ましさ]は，[評価対象空間美観]やオフィスに植物があると良 いと思うかという自然観を尋ねた[オフィスに緑 $]$ 関係が強 いことが明らかになった。就業者がオフィスに緑があること を肯定的に評価する傾向は，緑化空間のデザイン評価にプラ

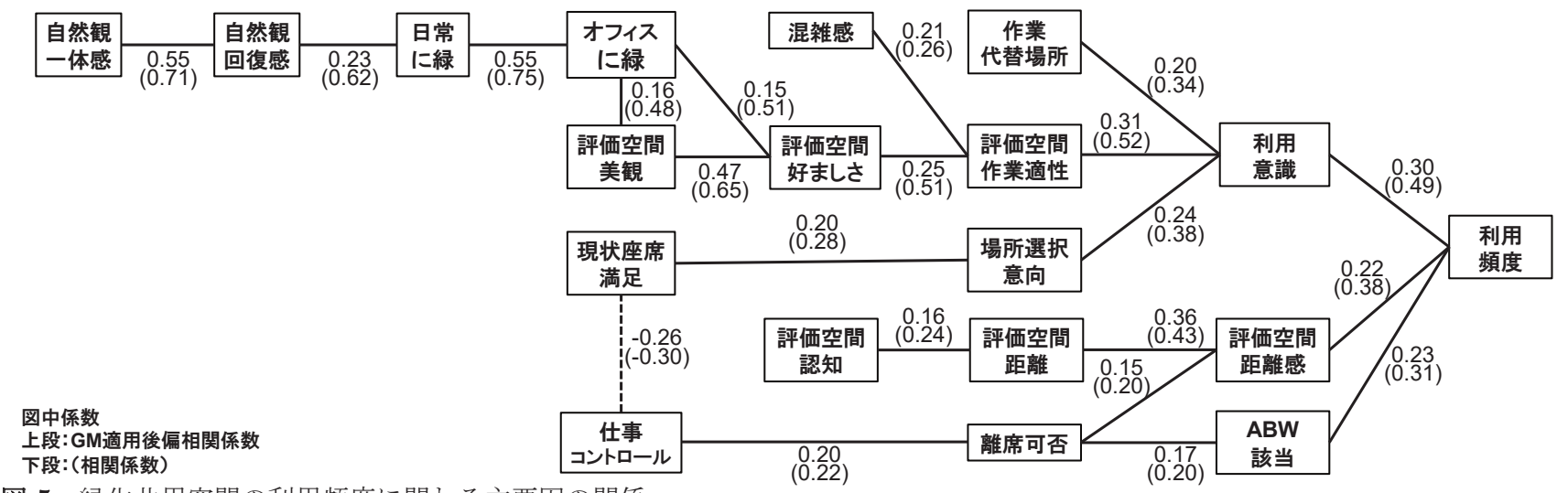

図-5 緑化共用空間の利用頻度に関わる主要因の関係

Fig. 5 Main factors involved in greening common space use 
ス方向に働きかけ，それが利用意識の形成を通して利用に影 響することが示された。こうした利用に至るまでの心理プロ セスを理解した上で, 緑化共用空間の利用を促進寸る方策を 検討することが重要と考えられた。

\section{4 研究手法の今後の課題}

本研究の主要な限界として 3 点ある。1 1 目は, 測定が主 観的アンケートによるため回答バイアスが含まれること。2 つ目は，横断調査によるため因果関係の推論には制約がある こと。3 つ目は, 未測定の交絡要因の存在を排除できないこ とである。これら限界を今後の研究の課題として捉えている。

\section{5. まとめ}

本検討では，緑化共用空間の利用促進に資する知見を得る ため, 特に一人で執務する際に緑化共用空間を利用する主要 因をGMに基づき把握した。その結果，緑化共用空間の一人 作業での利用には，就業者の利用意識だけでなく，ABWに 代表される裁量のある勤務形態や，緑化共用空間までの距離 感を感じさせない配置計画が重要であることが示された。

また利用意識の形成には, 緑化共用空間が一人作業をする のに適しているかというデザイン評価に加え, 就業者が一人 作業をする際に場所を選んで執務したいと考えているかとい う就労スタイル，他に作業場所があるかという就業者が置か れている執務環境が影響することが示された。

緑化共用空間の一人作業における利用促進は, 緑化空間の 配置計画に加え, 企業の就労制度や就業者の執務に関する意 識変容への働きかけを含めた多角的なアプローチにより達成 できると考えられた。また, 利用意識の形成には, 空間が作 業に適した場所であると評価されることが必要であり, 緑化 空間の意匠設計も重要な役割を果たすと予想される。今後, 植物の配置や量など緑化空間デザインが就業者の空間評価に 与える影響について, 定量的な評価に取組むことで, より具 体的な緑化共用空間の計画手法の構築が期待できる。

健康経営を推進する企業では, 執務環境への緑化など自然 要素の導入は今後の施設計画におけるスタンダードになる。 本報で得られた知見をもとに緑化共用空間を効果的に設けて 就業者の利用を促進寸ることで，より健康で生産性の高い執 務状態を日常的に維持できるオフィス空間実現を目指す。

謝辞 : 本研究は, JST-OPERA（JPMJOP1831）の助成を 受けて実施した。記して深謝します。

\section{引用文献}

1）長谷川祥子・下村孝（2013）室内の植物が人間の心身に及 ぼ寸影響に関わる研究の現状と今後の課題. 日本緑化工学 会誌, 39: 552-560.

2）川瀬雅也・松田史生(2017) 相関と相関係数. 生物工学会誌, 95: 494-497.

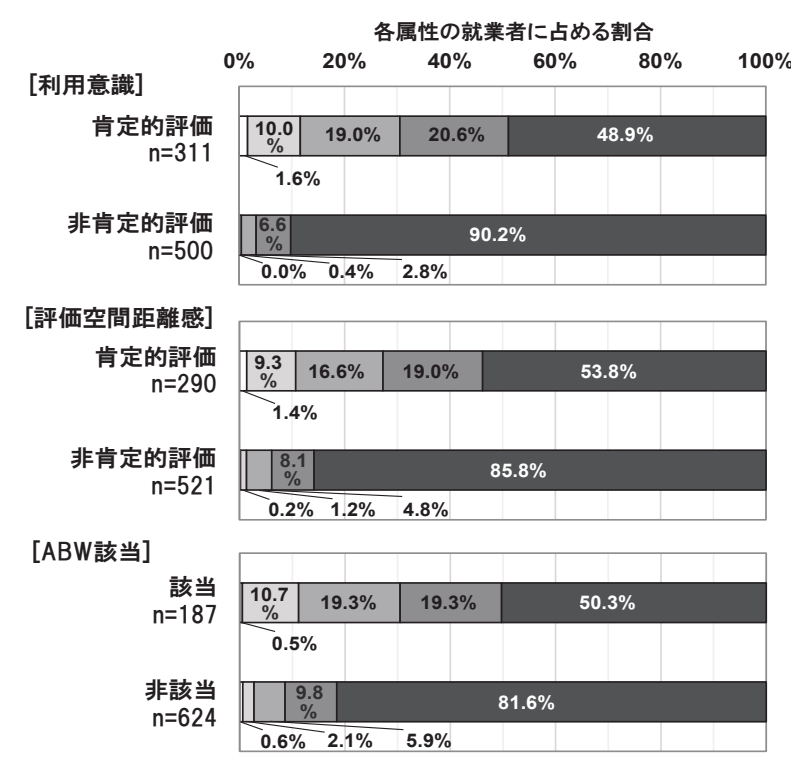

口ほとんど每日 ロ週に2-3回程度 口週に1回程度 ロ2週に1回程度 ロ月に1回以下

図-6 就業者属性が緑化共用空間の利用頻度に与える影響

Fig. 6 Impact of employer attributes on probability of use

3）川島実(2020) Well Building Standard の概要について. BELCA news, 32: 65-70.

4）厚生労働省(2021）労衔安全衛生法に基づくストレスチェ ック制度実施マニュアル。

5）宮川雅巳（1997）グラフィカルモデリング. 朝倉書店, pp. 88-95.

6）大塚芳嵩 - 那須守・岩崎寛(2020) 機械学習による都市公園 の利用についての誘発要因に関する推論. 日本緑化工学会 誌, 46: 45-50.

7）齋藤翔馬 - 林立也 - 樋山恭助 - 久保隆太郎 (2020) CASBEEウェルネスオフィスの開発と評価内容の概要. 日本建築学 会技術報告集, 26：625-630.

8）佐藤泰・佐野友紀・小島隆矢(2017) ワーカーの個人属性と オフィス内行動毎の環境選好の関係. 日本建築学会環境系 論文集, 82: 715-725.

9）芝田征司（2016）自然に対する感情反応尺度の作成と近隣 緑量による影響の分析. 心理学研究, 87: 50-59.

10）下光輝一 (2005) 職業性ストレス簡易調査票を用いたスト レスの現状把握のためのマニュアル. 平成 14 年〜 16 年度 厚生労働科学研究費補助金労働安全衛生総合研究。

11）杉浦敏弘・橋本哲・寺野真明・中村政治・近藤靖史・川瀬 貴晴 (2006) ワークプレイスプロダクティビティの主観的 評価手法. 空衛学会大会学術講演論文集, 151-154.

12) Veldhoen Company (2020) Activity Based Working : Research on measurable outcomes and key defferentiators.

13）矢動丸琴子・中村勝・岩崎寛 (2017) オフィス緑化が勤務者 に与える影響に関する研究一業種・職種別による考察一。 日本緑化工学会誌, 43: 86-91. 